\title{
The Role of Science Literacy Based Ta'lim Andragogy as an Alternative Media in Strengthening Covid-19 Awareness:
}

\author{
A Review \\ Ahmad Husein Ritonga* \\ Postgraduate \\ State Islamic University of Sulthan Thaha Saifuddin \\ Jambi, Indonesia \\ *husein_ritonga@yahoo.com \\ Minnah El Widdah \\ Management Education Department, Postgraduate \\ Islamic State University of Sulthan Thaha Saifuddin \\ Jambi, Indonesia \\ elwiddah01@gmail.com
}

\author{
Sukarno \\ Physic/Science Education Department, Tarbiyah and Teacher Training Faculty \\ Islamic State University of Sulthan Thaha Saifuddin \\ Jambi-Indonesia \\ sukarno@uinjambi.ac.id
}

\begin{abstract}
At the end of December 2019, a virus, currently known as the novel coronavirus-2019 or 2019 novel coronavirus (2019-nCoV), has emerged with a relatively fast spread rate. Each individual is obliged to participate in the process of preventing the disease from spreading. Additionally, any elements of society should have positive contributions in preventing the spread of this disease, including the non-formal religious education. In this study, the role of Ta'lim andragogy, a non-formal teaching-learning process for adults adopted teacher centered learning, in preventing the spread of coronavirus is investigated. Thus, the focus of this research is to exercise how the concept of ta'lim andragogy based on Science and Al-Quran Literacy can be implemented in strengthening awareness on covid-19. This study uses a qualitative approach with data collection methods through literature review. The data used in this research were mainly originated from text, both in the form of manuscript text (books, magazines, journals, newspapers, etc.) or digital text. Theoretically, ta'lim has a potential as an alternative method in increasing this covid-19 awareness. For this reason, andragogy $\mathrm{ta}^{\prime} \mathrm{lim}$ must be modified in such a way, such as by integration with the values coming from the Qur'an, hence creating a new model of ta'lim based on Qur'anic literacy and scientific literacy.
\end{abstract}

Keywords— ta'lim andragogy, and quranic and science literacy, COVID-19

\section{INTRODUCTION}

A virus which is currently named as the novel coronavirus2019 or 2019 novel coronavirus (2019-nCoV) [1] or hereinafter known as COVID-19 has emerged from Wuhan, China, and caused severe outbreaks in many cities in China and spread globally [2]. Coronavirus disease (COVID-19) is caused by SARS-COV2 and is a causative agent of a potentially fatal disease of great global public health concern [3]. Sohrabi [4] stated that COVID-19 is caused by a betacorona virus called SARS-CoV-2 which affects the lower respiratory tract and manifests as pneumonia in humans. According to Shereen, Khan, Kazmi, Bashir, and Siddique [5] Coronavirus disease 19 (COVID-19) is a viral infection that is highly contagious.

WHO has declared COVID-19 a pandemic and the Indonesian government has also declared COVID-19 a national disaster [6]. Even, Remuzzi and Remuzzi [7] stated that the spread of COVID-19 affects more than 100 countries in a matter of weeks. According to Syafrida [8] the impact of the Covid-19 outbreak has caused social problems to weaken the economy of the community and country. In addition, Hanoatubun [9] also stated that COVID-19 has also had an impact on difficulties in finding employment, it is difficult to meet daily needs and even almost all economic sectors in Indonesia are affected by Covid-19. In short, the spread of the Corona virus has had a negative impact on the world economy [10].

Referring to the health emergency situation followed by an economic, even political and social emergency, the Covid-19 problem must be immediately sought for a solution so that the negative impacts that arise can be reduced. For this reason, various countries have implemented various measures to limit and reduce the spread of COVID-19. In Indonesia, several regulations have been linked to reduce the spread of this virus, 
for example physical social restrictions, work from home, school restrictions and so on [6]. This was also supported by the emergence of various policies related to the prevention of Covid-19 [11], and some even suggested that a lockdown be implemented in anticipation of a more widespread spread of the virus [11], as was done by India [12]

Efforts to prevent COVID-19 as a contagious and dangerous disease must be carried out quickly, accurately and systematically. Prevention is quickly, accurately and systematically carried out so that the disease can be controlled immediately and the spread process can be stopped immediately. The process of preventing the spread of the disease can be carried out if each individual has a good awareness to participate in participating in prevention. It is understood that one of the efforts to prevent infectious diseases such as COVID-19 is through the development of awareness of the healthy life of each individual in the community to actively participate in following health protocols as determined by WHO and the local government. This is as stated by Karo [13] that awareness of healthy living independently can prevent disease, improve health, and play an active role in creating a healthy environment.

The educational process has a very important role in fostering awareness of every student in order to have an awareness of healthy living. The awareness of good behavior (character) can be developed through the educational process. This is also in line with the opinion of Wedan [14] that the purpose of education is for students to actively develop their potential to have religious spiritual strength, self-control, personality, intelligence, noble character, and skills needed by themselves and society. Sujana [15] also states that education aims to develop the potential of students to become human beings who believe and fear God Almighty, have noble character, are healthy, knowledgeable, capable, creative, independent, and become democratic and responsible citizens. Therefore, creating students who have awareness and ability to prevent COVID is part of efforts to achieve educational goals.

However, the goals of education as mentioned above generally only touch students in formal education institutions (schools). As for the COVID-19 era, almost all schools (formal education) were closed by the government and replaced with online learning with the help of an internet network. Meanwhile, most of the areas in the Republic of Indonesia are still in rural areas that do not have good internet access. In addition, the emergence of other problems, such as the low digital literacy of teachers and students, inadequate mastery of online education applications, add to other problems in the education process. Thus the efforts to prevent COVID-19 by formal educational institutions (schools) do not run optimally.

In addition, formal education has not yet reached the general public, this is because formal education is limited to the age of learning citizens. Meanwhile, there are still many Indonesian citizens who have not received formal education, so illiteracy in Indonesia is still relatively high and is one of the most serious problems in Indonesia [16]. Meanwhile, illiteracy is one of the factors that hinders the quality of human resources [17]. Therefore, there must be a solution, so that the prevention of COVID-19 will involve all members of the community, so that it can run effectively.

In addition, referring to the educational objectives above, as stated by Sujana [15], that to produce students who have awareness in healthy living can also be done through religious education. Islam as a religion has a very interesting concept and has the potential to be an important means of preventing infectious diseases including COVID-19. This is because one of the concepts of Islamic teachings is education. One model of education in Islam is known as ta'lim. This is as mentioned by the Ikhwan [18] ta'lim in general, covering teaching and education.

Ta'lim, which is known as a means of teaching and education in Islam, has actually been going well. However, the learning activities in the ta'lim are still strictly religious in nature. What this means is that the material of knowledge discussed in the ta'lim is generally and as a whole still related to religious teachings which are understood in a narrow manner, which is oriented solely in the afterlife. Whereas Islam is a religion that pays great attention to human life as a whole (world and hereafter). Therefore, what has been going on so far is still considered unable to answer the problem of the still weak awareness of the community (Muslims) in preventing COVID-19. Therefore, the ta'lim process must be modified in such a way so that citizens learn to acquire knowledge that is not only oriented towards the afterlife but also oriented towards the life of the world, including in terms of disease prevention.

Referring to the explanation above, it can be understood that this study seeks to optimize the ta'lim process in which students are adults to increase public awareness in preventing the spread of COVID-19. This is intended in addition to involving community members in preventing the COVID-19 disease, as well as introducing the concept of adult education through ta'lim educational institutions which are well known in Islam. Thus, the focus of this research is to answer the question of how the concept of ta'lim andragogy is based on Science and Al-Quran Literacy as an Alternative Effort to Strengthen Awareness to Prevent Covid-19.

\section{Methods}

This study uses a qualitative approach with data collection methods through literature review. Thus the data used and studied in this study comes from text, both in the form of manuscript text (books, magazines, journals, newspapers, etc.) or digital text. Qualitative data is data that is expressed in the form of words, sentences and pictures [19]. The main requirement of data source texts in this study is that they are relevant to the problems studied in this study, namely ta'lim andragogy Based on Science Literacy and the Koran as an Effort to Strengthen Awareness to Prevent Covid-19. Thus, qualitative data and qualitative data collection techniques are descriptive in the form of spoken or written words about observable human behavior [20]. Prior to the analysis, the data 
were validated using triangulation techniques. This is as stated by Bachri [21] that checking data to gain confidence in the correctness of data in qualitative research can be done by triangulation. The data analysis used in this study is to use content analysis techniques. However, the analytical activities in this study were carried out together with the data collection itself. This refers to the opinion of Rijali [22] that qualitative data analysis activities are integrated with data collection activities, data reduction, data presentation, and the conclusion of research results. This is also in line with the opinion of Suyitno [23] that qualitative research is descriptive research and tends to use an inductive analysis approach.

\section{RESULTS AND DISCUSSION}

\section{A. Ta'lim Andragogy}

In the language ta'lim comes from Arabic, from the root words "allama" and "yu allimu" which means teaching and teaching which in English can be referred to as "instruction" [24]. This is also in line with Ridwan's [25] opinion that ta'lim comes from the root word alama-ya'malu which means: to spell or give a sign; and the basic word "alima-ya'malu" which means: to understand, to know something or to give a sign. Thus ta'lim can be interpreted as a learning process (education) through spelling and marking (reading) activities so that students understand, know and are able to do it independently. In short, ta'lim can also be said to be a teaching-learning process. The "andragogy" comes from the Greek term andr which means adult and agogus or agogos which means to lead or guide. Andragogy is the art and science of teaching adults in learning, a way to help adults learn according to their needs or an effort to motivate adults to learn to use their experiences to achieve new learning experiences. So andragogy is a learning method used for adult education [26]. The term andragogy is often found in the adult learning process, both in the nonformal education process (outside school education) and in the formal education learning process [27]. Thus ta'lim andragogy can be understood as a briefly ta'lim can also be said to be a teaching-learning process in adults.

As a teaching and learning activity that has an educational institution/organization, ta'lim also has a ta'lim institution known as majelis ta'lim. Majelis ta'lim is a non-formal diniyah education institution that aims to increase faith and devotion to Allah SWT and noble morals for its congregation, as well as to realize grace for the universe [28]. Majelis ta'lim are also a vehicle for strong interaction and communication between the common people and converts, and between members of the majelis ta'lim congregation without being limited by place, time and age [29]. Therefore, majelis ta'lim has a very good opportunity in providing insight and knowledge to learning citizens in accordance with the objectives of education in general, namely students actively develop their potential to have religious spiritual strength, self-control, personality, intelligence, noble character, as well as the skills needed by him and the community [14] including insight and knowledge about healthy living and prevention of COVID-19.
The opportunity for majelis ta'lim in order to strengthen public awareness through the process of education andragogy can be seen from the role of majelis ta'lim itself. In Islamic society assemblies have a very important role, especially through recitation activities in fostering religious awareness, shaping Muslim personalities, improving the ability to read and write the Qur'an and its understanding; and guide towards an Islamic view of life [30]. This is also in line with the opinion of Mujahidin [31] that the existence of majlis ta'lim in society is very important. This is because majelis ta'lim have a strategic position and role, in conveying the values of da'wah in society. In addition, Setiawati [32] also said that as a center for Islamic learning, majelis ta'lim was recognized as having contributed a very big role in participating in educating the life of the people and the nation, especially in teaching religion and strengthening the nation's morals.

The existence of Majelis Ta'lim as a non-formal Islamic education institution has an important role in the process of socialization and acculturation to bring Muslims into a diverse cultural life [33]. In fact, according to Nugraha [34] majelis ta'lim can be used as a center for community empowerment. The results of the study Fransori, Sulistijani, and Youlinda Parwis [35] show that majelis ta'lim can be used as a means of educating parents' care for children in strengthening children's character education and digital literacy in the ta'lim assembly participants.

The strategic role of majelis ta'lim as a means of community empowerment in preventing the COVID-19 disease is also evident from the public perception of majelis ta'lim itself. In society, the existence of majelis ta'lim is often used as a means of lifelong education [36]. This is due to the uniqueness of the ta'lim assembly itself, which is open to all ages and social strata. This is as stated by Syamsidar [29] that majelis ta'lim are open to all ages, social strata or strata, and gender. In addition, majelis ta'lim are also a means for the community to implement the values of Islamic teachings themselves. Muslims understand that Islamic values are not only known, understood, and lived but must also come to the level of their practice in everyday life [30].

In the process of its implementation, this ta'lim assembly is strongly influenced by the socio-cultural and economic conditions of the congregation and kyai. This can be seen from the selection of subject matter, the learning process, and its management. The subject matter chosen is the main material for Islamic teachings at the basic level. The learning process is dominated by the teacher as a single learning source [37]. From this point of view, the socio-cultural and economic conditions of the congregation and kyai increasingly give the impression of the importance of majelis ta'lim to play an active role in strengthening public awareness in the process of preventing this COVID-19. This is because the selection of the material (content) can be adapted to the existing situation and conditions. Of course, in the current situation (the COVID-19 pandemic), the kyai (teachers of the ta'lim council) can choose materials that are appropriate to the situation. 
As mentioned above, the educational process in majelis ta'lim is generally followed by adult learning citizens. Therefore, the educational process and the method of implementing the education are also adult education, which is known as andragogy. This is in line with Anwar's [26] opinion that andragogy is the art of educating adults in the learning process, teaching techniques to help them learn according to their needs, and efforts to motivate them to learn by using their experiences to gain new learning experiences. In addition, Padmowihardjo [38] also states that Andragogy is the science of how to lead or guide adults or the science of teaching adults.

To teach adults through adult education can be done with various methods and strategies that are needed. In this case, adults as students in learning activities cannot be treated like ordinary students who are sitting in traditional schools. Therefore, it must be understood that adults who grow as individuals and have a maturity of self-concept move from dependence as happened in childhood towards independence or self-direction [39]. Thus the learning process at majelis ta'lim with andragogy learning techniques can run more effectively [40].

Based on the research, it was found that the learning process using the andragogical approach had a considerable impact in building student learning motivation, especially as shown in the intensity of attention during lectures, consistency in doing assignments and lecture evaluation, and improved achievement of course passing criteria [41]. Adult education is one approach in the implementation of non-formal education because most of the students are adults, who come with different socio-cultural backgrounds, experiences, interests, and different goals. Low learning outcomes as an indicator of unsuccessful learning, where participants are unable to properly accept learning materials taught by tutors is a problem in no formal education.

\section{B. Ta'lim Andragogy based on Qur'anic and Science Literacy as an alternative in strengthening the prevention of COVID-19.}

The opportunities and strategic role of majelis ta'lim in an effort to increase public awareness to actively participate in the prevention of COVID-19 are not in doubt. However, in order for the ta'lim andragogy to run effectively and efficiently, it is necessary to modify the learning process. Modification of the ta'lim andragogy process can be done either, material/content, or media. Modifications to the ta'lim andragogy process are seen to be made easier, given the position of the ta'lim council which is not a formal education, so that changes can be made by teachers (ustad/kyai) without having to wait for the approval of the government or certain educational institutions either in the case of material/content and media. In addition, the ta'lim participants almost never questioned the ta'lim material presented by the speakers as long as they are based on Qur'an and hadith.

In an effort to increase public awareness (ta'lim participants) to actively participate in the prevention of
COVID-19, modification of ta'lim and media materials must be in line with the existing situation, namely the COVID-19 pandemic. It is intended that the participants are literate about COVID-19 as an initial step in awareness of preventing the disease. This is in line with the definition of literacy as a person's ability to understand and process information through reading and writing [42]. This is in line with the opinion of Perry [43] that literacy is the ability to write, read, speak, extract, construct, integrate and criticize a phenomenon that occurs. According to Gee [44] literacy as a control of language use, both language as a natural process (means of communication) and language as a formal process of language learning (science). Literacy is a human right and is a basic element of the right to education [45]. Thus, if the participants of Muslim andragogy are literate about COVID-19, their awareness to take precautions will also be better.

The implementation of ta'lim andragogy in order to improve participants' literacy against COVID-19 must still be sourced from the Qur'an, because Muslims believe that all aspects of human life can be resolved with it [46]. In addition, Al-Qur'an and Al-Sunnah invite Muslims to seek and gain knowledge and wisdom, and place knowledgeable people at a high degree [42]. Al-Quran which is the first source for Muslims as a way of life contains the purpose behind its great educational messages for mankind [27]. Therefore, literacy material for disease must still refer to the main sources of Islamic law, namely Al-Quran and hadith. This is of course a challenge for the ustadz/kyai or resource persons in the ta'lim andragogy process.

Regarding infectious diseases, the ustadz/kyai as teachers in the ta'lim assembly can start by reading verses or hadiths related to them, for example; "Avoid people with leprosy like you prevented from a lion (H.R al-Bukhari)", or another hadith which says "If you hear that there is a disease epidemic in a country then don't enter it; and if (the plague) occurs while you are in the land, then do not go out and flee (H.R Al-Bukhari)" [18]. By knowing and understanding this hadith, awareness will emerge that avoiding and preventing infectious diseases is part of Islamic teachings. Therefore, with the increased insight and belief/faith of the participants of ta'lim andragogy, their awareness will also increase.

In addition to the material or content in the ta'lim andragogy which must be based on Quran literacy, material enrichment is needed so that the knowledge and literacy of Muslim participants about COVID-19 also increases. The enrichment of andragogical ta'lim material must be linked to the scientific study of COVID-19 (scientific literacy). This is intended so that participants of ta'lim andragogy in addition to understanding that the prevention of COVID-19 is part of Islamic teachings, they also understand scientifically related to the disease. Insights and scientific knowledge related to the disease can be started from the history of its appearance, the nature/character of the disease, the speed of transmission, the process of prevention and so on. With this information, the knowledge and insight of the Muslim participants will increase, thus triggering the growth of awareness to actively participate 
in preventing the transmission of COVID-19 to themselves, their families and the surrounding environment.

Referring to Zuriyani's [47] opinion that scientific literacy is the ability to use scientific knowledge, identify questions, and draw conclusions based on evidence, in order to understand and make decisions regarding nature and changes made to nature through human activities. In addition, scientific literacy can also be said to be an understanding of science and its processes, as well as its application for community needs [47]. Thus, participants of ta'lim andragogy with their ta'lim material based on scientific literacy, they will be able to use this knowledge (about COVID-19) to draw conclusions based on scientific evidence as a basis for decision making (aware of the prevention of COVID-19).

In addition, scientific literacy is also closely related to knowledge and technology. Therefore, scientific literacy based ta'lim andragogy will also have a positive impact on Muslim participants to participate in various public activities. This is as stated by Yuliati [48] that scientific literacy has the potential to empower people to make personal decisions and participate in the formulation of public policies that have an impact on their lives. Anjarsari [49] in her research also states that scientific literacy is very important to solve various problems related to ethics, morals and global issues due to rapid changes in science and technology. Carin, A.A. and Sund [50] also states that science as part of education plays an important role in preparing students who have scientific literacy, who are able to think critically, creatively, logically, and take the initiative in responding to issues in society caused by the impact of the development of science and technology. This argument further strengthens the role of ta'lim andragogy in increasing public awareness to prevent the spread of COVID-19 independently.

Seeing the current situation, in Indonesia in general and in particular in Jambi province, it can be seen that public awareness of COVID-19 prevention is still relatively low. There is even a group of people who do not believe in this disease for various reasons. In addition, some groups in society neglect prevention for some reason. This situation has resulted in a tendency for an increasing number of people to be exposed to this disease. This situation is thought to be strong evidence that they are not literate towards science well. This is in accordance with the opinion of Nofiana and Julianto [51] that low scientific literacy causes students to be less responsive to developments and problems around the environment, especially those related to natural phenomena, local regional excellence, and problems in the surrounding environment.

Referring to the description above, it is clear that to increase public awareness in the process of preventing the COVID-19 disease with an integrated andragogy ta'lim. The integration that is meant is the integration of Al-Quran values and scientific values. The integration of scientific values based on the Qur'an can be done by using an interdisciplinary integration approach as a connecting concept between scientific literacy, Islamic values, and cultural values which in practice can be transferred through education [52]. Therefore, the educational process of the ta'lim andragogy model can be used as an alternative in an effort to increase public awareness to live healthy and aware of the importance of preventing a disease.

\section{CONCLUSION}

The level of public awareness for active and independent prevention is still relatively low, so it is necessary to take appropriate and systematic steps. Theoretically, ta'lim andragogy, namely learning in adults has the potential as an alternative in increasing this awareness. For this reason, andragogy ta'lim must be modified in such a way, namely integrated between the values of the Qur'an and scientific values, so that it takes the form of a new model of ta'lim, namely andragogy ta'lim based on Qur'an literacy and scientific literacy.

\section{ACKNOWLEDGMENT}

The author's gratitude and high appreciation to the Chancellor of the State Islamic University of Sulthan Thaha Saifuddin Jambi and all contributors who actively participated in this research.

\section{REFERENCES}

[1] Sun, P., Lu, X., Xu, C., Sun, W., \& Pan, B. (2020). Understanding of COVID-19 based on current evidence. Journal of Medical Virology. https://doi.org/10.1002/jmv.25722

[2] Wu, Y. C., Chen, C. S., \& Chan, Y. J. (2020). The outbreak of COVID19: An overview. Journal of the Chinese Medical Association. https://doi.org/10.1097/JCMA.0000000000000270

[3] Rothan, H. A., \& Byrareddy, S. N. (2020). The epidemiology and pathogenesis of coronavirus disease (COVID-19) outbreak. Journal of Autoimmunity. https://doi.org/10.1016/j.jaut.2020.102433

[4] Sohrabi, C., Alsafi, Z., O’Neill, N., Khan, M., Kerwan, A., Al-Jabir, A., ... Agha, R. (2020). World Health Organization declares global emergency: A review of the 2019 novel coronavirus (COVID-19). International Journal of Surgery. https://doi.org/10.1016/j.ijsu.2020.02.034

[5] Shereen, M. A., Khan, S., Kazmi, A., Bashir, N., \& Siddique, R. (2020) COVID-19 infection: Origin, transmission, and characteristics of human coronaviruses. Journal of Advanced Research. https://doi.org/10.1016/j.jare.2020.03.005

[6] Kemenkes RI. (2020). Pedoman Pencegahan dan Pengendalian Corona Virus Disease (Covid-19). In Direktorat Jenderal Pencegahan dan Pengendalian Penyakit.

[7] Remuzzi, A., \& Remuzzi, G. (2020). COVID-19 and Italy: what next? The Lancet. https://doi.org/10.1016/S0140-6736(20)30627-9

[8] Syafrida, S. (2020). Bersama Melawan Virus Covid 19 di Indonesia. SALAM: Jurnal Sosial Dan Budaya Syar-I https://doi.org/10.15408/sjsbs.v7i6.15325

[9] Hanoatubun, S. (2020). Dampak Covid-19 Terhadap Perekonomian Indonesia. Journal of Education, Psychology and Counseling.

[10] Burhanuddin, C. I., \& Abdi, M. N. (2020). Ancaman Krisis Ekonomi Global Dari Dampak Penyebaran Virus Corona (COVID-19). AkMen.

[11] Telaumbanua, D. (2020). Urgensi Pembentukan Aturan Terkait Pencegahan Covid-19 di Indonesia. QALAMUNA: Jurnal Pendidikan, Sosial, Dan Agama. https://doi.org/10.37680/qalamuna.v12i01.290

[12] The Lancet. (2020). India under COVID-19 lockdown. The Lancet. https://doi.org/10.1016/S0140-6736(20)30938-7 
[13] Karo, M. B. (2020). Perilaku Hidup Bersih dan Sehat (PHBS) Strategi Pencegahan Penyebaran Virus Covid-19. Prosiding Seminar Nasional Hardiknas. https://doi.org/978-602-202-076-9

[14] Wedan, M. (2016). Pengertian Pendidikan dan Tujuan Pendidikan Secara Umum.

[15] Sujana, I. W. C. (2019). Fungsi Dan Tujuan Pendidikan Indonesia. Adi Widya: Jurnal Pendidikan Dasar. https://doi.org/10.25078/aw.v4i1.927

[16] Simbolon, I. A. R., Yatussa'ada, F., \& Wanto, A. (2019). Penerapan Algoritma Backpropagation dalam Memprediksi Persentase Penduduk Buta Huruf di Indonesia. Jurnal Informatika Upgris. https://doi.org/10.26877/jiu.v4i2.2423

[17] Jessica, V., Halis, A., Ningsi, D. W., Virginia, G. F., \& Syahidah, (2017). Pemberantasan Buta Aksara untuk Peningkatan Kualitas Sumber Daya Manusia Masyarakat Sekitar Hutan Desa Manipi, Kecamatan Pana, Kabupaten Mamasa. Agrokreatif Jurnal Ilmiah Pengabdian Kepada Masyarakat. https://doi.org/10.29244/agrokreatif.3.2.136-142

[18] Ikhwan, I. (2019). Pendidikan Karakter dalam Perspektif Al-Qur'an. Mumtaz: Jurnal Studi Al-Qur'an Dan Keislaman. https://doi.org/10.36671/mumtaz.v2i1.17

[19] Sugiyono. (2018). Metode Penelitian Kuantitatif,Kualitatif dan R\&D. Ke-26.

[20] Ivanovich Agusta. (2014). Teknik Pengumpulan dan Analisis Data Kualitatif. Jurnal Studi Komunikasi Dan Media.

[21] Bachri, B. S. (2010). Meyakinkan Validitas Data Melalui Triangulasi Pada Penelitian Kualitatif. Teknologi Pendidikan.

[22] Rijali, A. (2019). Analisis Data Kualitatif. Alhadharah: Jurnal Ilmu Dakwah. https://doi.org/10.18592/alhadharah.v17i33.2374

[23] Suyitno. (2009). Penelitian Kualitatif. Journal Equilibrium.

[24] Ma'zumi, M., Syihabudin, S., \& Najmudin, N. (2019). Pendidikan Dalam Perspektif Al-Qur'an Dan Al-Sunnah: Kajian Atas Istilah Tarbiyah, Ta'lim, Tadris, Ta'dib dan Tazkiyah. TARBAWY: Indonesian Journal of Islamic Education. https://doi.org/10.17509/t.v6i2.21273

[25] Ridwan, M. (2018). Konsep Tarbiyah, Ta'lim Dan Ta'dib Dalam AlQur'an. Nazhruna: Jurnal Pendidikan Islam. https://doi.org/10.31538/nazhruna.v1i1.97

[26] Anwar, B. (2017). Konsep Pendidikan Andragogi Menurut Pendidikan Islam. Al Daulah: Jurnal Hukum Pidana Dan Ketatanegaraan. https://doi.org/10.24252/ad.v6i1.4864

[27] Hasyim, B. (2013). Islam Dan Ilmu Pengetahuan (Pengaruh Temuan Sains terhadap Perubahan Islam). Jurnal Dakwah Tabligh.

[28] Bariah, O., Hermawan, I., \& Nur, H. T. (2012). Peran Majelis Ta'lim Dalam Meningkatkan Ibadah Bagi Masyarakat di Desa Telukjambe Karawang. Solusi.

[29] Syamsidar, S. (2019). Strategi Komunikasi Majelis Ta'lim Nurul Ishlah Sebagai Media Pendidikan Dalam Meningkatkan Kesadaran Beragama. Jurnal Jurnalisa. https://doi.org/10.24252/jurnalisa.v4i1.5625

[30] Sarbini, A. (2014). Internalisasi Nilai Keislaman Melalui Majelis Ta'lim. Jurnal Ilmu Dakwah. https://doi.org/10.15575/jid.v5i16.355

[31] Mujahidin, M. (2019). Urgensi Majelis Ta'lim Sebagai Lembaga Dakwah Di Masyarakat. Alhadharah: Jurnal Ilmu Dakwah. https://doi.org/10.18592/alhadharah.v17i33.2372

[32] Setiawati, N. (2012). Majelis Ta'lim dan Tantangan Pengembangan Dakwah. Jurnal Dakwah Tabligh.

[33] Marzuki, A., Mohamad, M. Z., \& Baru, R. (2018). Role of Majelis Ta'lim and Adaptation Muslim Minority with Tengger Local Culture. International Journal of Academic Research in Business and Social Sciences. https://doi.org/10.6007/ijarbss/v8-i10/4730
[34] Nugraha, F. (2020). Majelis Ta'lim Sebagai Basis Pemberdayaan Umat. Tatar Pasundan: Jurnal Diklat Keagamaan. https://doi.org/10.38075/tp.v12i33.60

[35] Fransori, A., Sulistijani, E., \& Youlinda Parwis, F. (2019). Penyuluhan Pola Asuh Orang Tua Terhadap Anak Dalam Penguatan Pendidikan Karakter Anak Dan Literasi Digital Pada Ibu-Ibu Majelis Ta'lim AlHidayah Depok. Jurnal Pengabdian Masyarakat (JPM-IKP). https://doi.org/10.31326/jmp-ikp.v2i01.259

[36] Suherdi, D., Rahmat Hidayat, D., \& Abdurrahman, M. (2017). The Role of Majelis Ta'lims and Arabic Literacy in Sustaining Lifelong Learning in Indonesia. https://doi.org/10.2991/nfe-16.2017.41

[37] Khodijah, N. (2019). Majelis Ta'lim Asy Syifa Potret Majelis Ta'lim Dalam Komunitas Muslim Muallaf Di Bali. Ri'ayah: Jurnal Sosial Dan Keagamaan. https://doi.org/10.32332/riayah.v3i02.1321

[38] Padmowihardjo, S. (2014). Pengertian dan Konsep Pendidikan Orang Dewasa. Modul 1 Pendidikan Orang Dewasa

[39] Asmin. (2011). Konsep Dan Metode Pembelajaran Untuk Orang Dewasa (Andragogi). Jurnal Unimed Medan. https://doi.org/10.1016/j.jog.2012.02.009

[40] Hasyim, M. (2015). Andragogi Dalam Pembelajaran Bahasa Arab ARABIYAT: Jurnal Pendidikan Bahasa Arab Dan Kebahasaaraban. https://doi.org/10.15408/a.v2i1.1512

[41] Rahman, A., \& Elshap, D. . (2018). Implementasi Kekuatan Motivas Belajar dalam Pendekatan Andragogi. Jurnal Empowerment. https://doi.org/10.22460/empowerment.v5i2p1-12.548

[42] 43 Ahmad Zainuri, Sukarno, 2020. Does Qur'an and Science Literacy Interrelated? Talent Development \& Excellence Vol.12, No. 1, 2020, 3927-3939. https://www.iratde.com/index.php/jtde/article/view/1345/1039

[43] 44 Perry, K. H. (2012). What is literacy? -- A critical overview of sociocultural perspectives. Journal of Language and Literacy Education. https://doi.org/10.1017/CBO9781107415324.004

[44] 45 Gee, J. P. (2012). What is literacy? In Language and Linguistics in Context: Readings and Applications for Teachers. https://doi.org/10.4324/9780203929124

[45] 46 Keefe, E. B., \& Copeland, S. R. (2011). What is literacy? the power of a definition. Research and Practice for Persons with Severe Disabilities. https://doi.org/10.2511/027494811800824507

[46] 47 Hakim, H. (2018). Epidemi dalam AlQuran (suatu Kajian tafsir Maudhu'I dengan corak ilmi). . Kordinat.

[47] 48 Zuriyani, E. (2011). Literasi Sains Dan Pendidikan. Jurnal Sains Dan Pendidikan, 13. https://doi.org/10.1007/SpringerReference_300852

[48] 50 Yuliati, Y. (2017). LITERASI SAINS DALAM PEMBELAJARAN IPA. Jurnal Cakrawala Pendas. https://doi.org/10.31949/jcp.v3i2.592

[49] 49 Anjarsari, P. (2014). Literasi Sains Dalam Kurikulum dan Pembelajaran IPA Smp. Prosiding Semnas Pensa VI "Peran Literasi Sains".

[50] 51 Carin, A.A. \& Sund, R. . (2016). STEM Education: Inovasi dalam Pembelajaran Sains. Prosiding Seminar Nasional Pendidikan Sains.

[51] 52 Nofiana, M., \& Julianto, T. (2018). Upaya Peningkatan Literasi Sains Siswa Melalui Pembelajaran Berbasis Keunggulan Lokal. Biosfer: Jurnal Tadris Biologi. https://doi.org/10.24042/biosf.v9i1.2876

[52] 53 Asyhari, A. (2017). Literasi Sains Berbasis Nilai-Nilai Islam dan Budaya Indonesia. Jurnal Ilmiah Pendidikan Fisika Al-Biruni. https://doi.org/10.24042/jpifalbiruni.v6i1.1584

[53] 42 Bartin, T. (2018). Pendidikan Orang Dewasa Sebagai Basis Pendidikan Non Formal. Jurnal Teknodik. https://doi.org/10.32550/teknodik.v10i19.398 